\title{
Rapid production of organic fertilizer from degradable waste by thermochemical processing
}

\author{
C. R. Sudharmaidevi ${ }^{1}$ K. C. M. Thampatti ${ }^{1} \cdot$ N. Saifudeen ${ }^{1}$
}

Received: 22 June 2016/ Accepted: 22 November 2016/Published online: 3 December 2016

(c) The Author(s) 2016. This article is published with open access at Springerlink.com

\begin{abstract}
Purpose Chemical decomposition was studied as a potential method for the rapid conversion of waste to organic fertilizer.

Methods Chemicals were screened, and process parameters were optimized. The physicochemical properties, phytotoxicity, and manurial efficiency of the product were assessed. A prototype machine was fabricated for the operation.

Results Chemical treatment of ground fresh waste with $\mathrm{HCl}\left(0.25 \mathrm{~N}, 50 \mathrm{ml} \mathrm{kg}^{-1}\right)$ for 30 min followed by $\mathrm{KOH}$ $\left(0.5 \mathrm{~N}, 100 \mathrm{ml} \mathrm{kg}^{-1}\right)$ for $30 \mathrm{~min}$ at $100{ }^{\circ} \mathrm{C}$, and ambient pressure yielded a product that could be used in place of conventional organic manure. Only 8-14 h were required to complete the entire process. No by-product or leachate was produced. The quality of the product was comparable to that of conventional composts, except for the absence of microorganisms. The fortified organic fertilizer enhanced the yield of vegetables in pot trials. The process and the prototype machine were found beneficial by a public evaluation.

Conclusions The new thermochemical waste processing method provides a quick and sustainable solution for hygienic waste disposal and the production of organic fertilizer.
\end{abstract}

Keywords Quick recycling · Organic fertilizer · Pollution reduction $\cdot$ Thermochemical $\cdot$ Waste processing

C. R. Sudharmaidevi

sudharmaidevi@gmail.com

1 Department of Soil Science and Agricultural Chemistry, College of Agriculture, Vellayani Kerala Agricultural University, Trivandrum, Kerala, India 695522

\section{Introduction}

Scientific and hygienic waste disposal is a serious concern (Abu Qdais and Al-Widyan 2016) in developing countries, especially in urban areas, where the population density is high and the availability of land for waste processing and disposal is limited. The total municipal solid waste (MSW) generated in urban India is estimated to be 68.8 million tons per year or 188,500 tons per day (Annepu 2012). The current infrastructure available in the country is insufficient for the efficient handling and disposal of this huge quantity of waste on a daily basis (Baishya et al. 2016). Collected waste is often dumped in open land or used for landfilling. This leads to severe environmental hazards ( $\mathrm{Du}$ et al. 2014). Due to the scarcity of land, existing dumping yards are sometimes overfilled. Although incineration is increasingly being used for waste disposal (Dube et al. 2014), it cannot be advocated widely due to the associated toxic gas emissions (Kim and Kim 2010). An analysis of solid waste in the major cities of India revealed that $\sim 51 \%$ of it is composed of degradable organic material (Annepu 2012). Although this organic waste cannot be utilized as fuel because of its high moisture and low calorific value (Rana et al. 2013), the plant nutrient content makes it ideal for recycling as manure for crop production. The conversion of solid waste to organic fertilizer is a desirable option, in light of reports that severe depletion of soil organic matter is a major cause of declining crop productivity (Lal 2015). The use of organic fertilizers not only reduces the quantity of the organic fraction that ends up in landfills (Lim et al. 2016), but also reduces the use of inorganic fertilizers (Lim et al. 2015). Aerobic and anaerobic composting practices are popular in the country, but they are slow processes, limiting the turnover rate of waste recycling and disposal. Waste has to be collected from 
sources and transported to the composting yards, and largescale dumping near the units for long periods leads to severe environmental pollution. In addition, improper separation of the inert materials, such as plastics and glass, may degrade the quality of the final compost for agricultural purposes (Wu et al. 2014). In this context, a quick method for the conversion of source-segregated waste to organic fertilizer will help to overcome these problems.

Hydrolytic degradation of biomass employing acids/alkalis is a popular practice to obtain fermentation feedstock for the production of ethanol and other chemicals (Sharma et al. 2013; Adela et al. 2014; Elemike et al. 2015; Zhu et al. 2015). Organic materials can be subjected to rapid hydrolytic degradation by treatment with acids and alkalis, and the reaction can be further accelerated by heat (Sharma et al. 2013; Zhu et al. 2015). However, the use of chemical digestion for the rapid conversion of waste to organic fertilizer has not been attempted. Therefore, a study was conducted at Kerala Agricultural University, India, from 2009 to 2014 to investigate the possibility of chemical decomposition as a quick method for the production of organic fertilizer from degradable waste.

\section{Materials and methods}

\section{Waste: collection and characterization}

Degradable waste, segregated at the source, was collected from the canteens, student hostels and agricultural farms of the College of Agriculture, Kerala Agricultural University, Vellayani, India. The composition of the waste was analyzed, and a representative $1 \mathrm{~kg}$ sample was taken from the collected waste, air-dried, oven-dried at $60{ }^{\circ} \mathrm{C}$, and stored in an air-tight container for the determination of its physical and chemical properties.

\section{Laboratory screening trials}

Screening trials were conducted to select the most suitable chemical combination and optimum conditions for the degradation of organic waste. Two acids, i.e., $\mathrm{HCl}$ (Thys and Aires 2013; Elemike et al. 2015) and $\mathrm{H}_{2} \mathrm{SO}_{4}$ (Adela et al. 2014; Zhu et al. 2015), and an alkali, KOH (Bensah and Mensah 2013; Sharma et al. 2013), which are commonly used for hydrolytic degradation of biomass, were selected. Two concentrations $(0.25$ and $0.5 \mathrm{~N})$ of the chemicals and two temperatures $\left(100\right.$ and $150{ }^{\circ} \mathrm{C}$ ) (Maeda et al. 2013; Elemike et al. 2015; Zhu et al. 2015) were tested. Reaction times of $30 \mathrm{~min}$ (15 min each for acid and alkali) and $60 \mathrm{~min}$ (30 min for the acid and alkali) were adopted (Maeda et al. 2013; Elemike et al. 2015). A total of 32 combinations were tested. The collected waste was homogenized, and $500 \mathrm{~g}$ of the fresh sample was transferred to a $2 \mathrm{~L}$ glass beaker and placed in a custom-made thermostatic digester with an automatic stirrer. Acid was added at a rate of $50 \mathrm{ml} \mathrm{kg}^{-1}$ waste and was allowed to react for the specified time. Then, the alkali was added and allowed to react for the remaining time. The quantity of alkali was adjusted $\left(50 \mathrm{ml} \mathrm{kg}^{-1}\right.$, which was increased to $100 \mathrm{ml} \mathrm{kg}^{-1}$ ) to obtain a neutral endproduct. The $\mathrm{pH}$, color, electrical conductivity (EC), and total organic carbon (TOC) were recorded.

\section{Phytotoxicity tests}

The digest from the selected treatments was subjected to phytotoxicity bioassays in the laboratory using 1:10 (w/v) aqueous extract (Zucconi et al. 1985; Paradelo et al. 2010). Twenty seeds of Amaranthus sp. and ten seeds each of Vigna unguiculata (L.) Walp and Abelmoscus esculentus (L.) Moench were sown in Petri dishes lined with filter paper. The selection of the plant species was performed as described in OECD-OCDE (Organization for Economic Co operation and Development (2006). Distilled water was used as a control. Three replications of each species were kept in an incubation chamber at $28{ }^{\circ} \mathrm{C}$ for 5 days. The germination percentage and root length were recorded, and the germination index was calculated (Zucconi et al. 1985; Gariglio et al. 2002). Germination tests were also conducted using pro trays (OECD-OCDE (Organization for Economic Co operation and Development 2006). The potting mixture used to fill the trays was prepared by mixing sterilized coir pith and the digest in a 2:1 ratio. A growth medium of coir pith and vermicompost in a ratio of $1: 1$, which is the standard medium used on the Agricultural Farm of the college, was used as the control. The germination index was calculated according to Asgharipour and Sirousmehr (2012). The best treatment from these tests was selected for further evaluation.

\section{Evaluation of the selected method with existing bioconversion methods}

A comparative evaluation of the new process was performed with the existing composting methods to draw conclusions about the efficiency of the process and quality of the product. In this experiment, the selected thermochemical method, (1) mechanical disintegration and thermochemical decomposition at $100{ }^{\circ} \mathrm{C}$ for $60 \mathrm{~min}$ (MTC), was compared with the most commonly practiced methods in India, (2) mechanical disintegration followed by microbial composting (MMC), (3) mechanical disintegration followed by conventional aerobic composting (MCC), (4) vermicomposting (VC), and (5) conventional aerobic composting (CC). A $5 \mathrm{~kg}$ fresh waste sample was used in 
each treatment, and the experiment was performed in triplicate. The period required by each method for composting and the quality of the product obtained were studied. The maturity parameters prescribed for composts produced by bioconversion were taken as a reference in the absence of specifications for thermochemical products. Since the digest was free of microorganisms due to the intense physicochemical treatment, only the physical and chemical properties, such as color, odor, $\mathrm{pH}, \mathrm{EC}, \mathrm{TOC}$, and $\mathrm{C}: \mathrm{N}$ ratio, were assessed. After fortification with calculated doses of essential plant nutrients to make it balanced, the new product was denoted fortified organic fertilizer (FOF).

\section{Evaluation of crop performance with FOF}

The manurial efficiency of FOF was compared with that of commonly used manures, i.e., farm yard manure (FYM) and vermicompost $(\mathrm{V})$, in pot culture experiments using vegetables (chili, tomato, and brinjal) as test crops. The experiment used a completely randomized design with four treatments and four replicates. Nitrogen, phosphorus, and potassium were applied to pots receiving FYM and V as per standard recommendations of Kerala Agricultural University. The growth and yield of the plants were recorded.

\section{Physicochemical properties of the thermochemical digest with and without fortification}

The moisture content of the samples was determined gravimetrically. The $\mathrm{pH}$ and EC was measured as described by Sasaki et al. (2003). pH was measured using a pH meter (Cyber Scan PC510, EuTech Instruments, Singapore), and EC was measured using an EC-TDS analyzer (CM183, Elico, India). TOC and $\mathrm{N}$ were determined using a CHNS analyzer (vario El cube, elementar, Germany). After nitricperchloric (4:1) wet digestion (Abbruzzini et al. 2014) of the samples, total $\mathrm{P}$ was analyzed by the vanadomolybdic yellow color method (Greenberg et al. 1992). K, Ca, and $\mathrm{Mg}$ were analyzed by atomic absorption spectrophotometer (novAA $350 \mathrm{BU}$, AnalytkjenaAG, Germany), the heavy metals $\mathrm{Pb}, \mathrm{Cd}, \mathrm{Ni}, \mathrm{Cr}$, and As were analyzed by inductively coupled plasma optical emission spectrometer (ICP OES Optima 8000, Perkin Elmer Inc., USA), and B was analyzed by the Azomethine-H method (Roignavarro et al. 1996).

\section{Fabrication of a prototype machine for the thermochemical processing of waste and the public evaluation trial}

An automated machine with a $20 \mathrm{~kg}$ capacity was designed and fabricated to implement the new technology. A larger capacity machine $(100 \mathrm{~kg}$ ) was installed in June 2015 , in a residential colony in Trivandrum, Kerala, India, for public evaluation.

\section{Economic and statistical analyses}

Since the unit installed in the residential colony represents the actual waste processing situation, cost analysis was performed based on the expenditure incurred and income generated by the unit. Statistical analyses of the data of the crop growth experiment were conducted using two-way analysis of variance (ANOVA). The $F$ values for treatments were compared with the table values. If the values were significant, the $C D$ values at the $5 \%$ significance level were calculated to compare the means and to interpret the results. For all other data, the means and standard deviations were calculated.

\section{Results and discussion}

The degradable waste collected from the campus had the average composition listed in Table 1 . Food waste was the dominant fraction, contributing $78 \%$. The raw waste was acidic ( $\mathrm{pH} 4.2$ ), because Indian cookery employs vegetables, spices, condiments, and other ingredients that are acidic in nature. Biowastes are universally reported to be acidic (Sundberg et al. 2013; Junoh et al. 2015). The moisture content was high $(82.5 \%)$, and the color varied with the components. A foul smell developed within $24 \mathrm{~h}$ due to the decomposition of food particles and the release of volatile organic compounds and gases (Du et al. 2014). The mean organic carbon and nitrogen contents were 34.5 and $1.08 \%$, resulting in a high $\mathrm{C}: \mathrm{N}$ ratio of 31.94 , which restricted its direct application to soil for crop production. The addition of organic materials with $\mathrm{C}: \mathrm{N}$ ratios $>30$ affects plant growth due to immobilization of the available $\mathrm{N}$ pool by soil microbes, restricting $\mathrm{N}$ availability to plants (Ahmad et al. 2006).

Table 1 Composition of waste collected from the campus

\begin{tabular}{llc}
\hline Sl. no. & Components & Average \% \\
\hline 1 & Vegetable peelings & 46.5 \\
2 & Food waste & 18.0 \\
3 & Fish waste & 5.5 \\
4 & Fruit waste & 8.0 \\
5 & Garden litter & 8.0 \\
6 & Agricultural wastes & 12.0 \\
7 & Inert materials & 2.0 \\
\hline
\end{tabular}

Values are average of 12 lots 


\section{Selection of the process conditions}

Laboratory screening aimed to develop a process for the fast and environmentally friendly conversion of stubborn and offensive organic waste materials into a product that can be conveniently used to promote the growth of crop plants. Since MSW is composed of plant and animal wastes, both acids and an alkali were screened. Although $\mathrm{NaOH}$ is (Maeda et al. 2013; Adela et al. 2014) an efficient hydrolytic agent for the degradation of biomass, it was not considered due to the undesirable effects it has on soil characteristics and plant growth (Suarez et al. 2006; Qadir et al. 2007). A reaction time of $30 \mathrm{~min}(15+15)$ was insufficient, since some of the original waste particles were identifiable after $30 \mathrm{~min}$, indicating incomplete degradation. Therefore, $60 \min (30+30)$ was selected. Alkali at a rate of $50 \mathrm{ml} \mathrm{kg}^{-1}$ was also not sufficient, since all the treatments except one had a pH less than 7 upon completion of the reaction time of $60 \mathrm{~min}$, and the color ranged from greenish-brown to black. The physical characteristics, such as color, odor, and temperature, provided a general idea of the decomposition stage (Bernal et al. 2009). The acidic reaction might be due to the inherent acidic nature of the raw waste used for the study. Some components in the waste exhibited $\mathrm{pH}$ values $<4$, which required the addition of a higher quantity of alkali to attain a neutral $\mathrm{pH}$ at the end of the reaction. When the experiment was repeated with the addition of a higher quantity of alkali $\left(100 \mathrm{ml} \mathrm{kg}^{-1)}\right.$, the desired $\mathrm{pH}$ and color were recorded in several treatments. The EC and TOC were also recorded. Although all the treatments effectively reduced the organic carbon content to levels comparable to common organic manure, only those with a brownish-black color, viscous consistency, safe EC, permissible TOC, and near neutral $\mathrm{pH}$ at the end of the processing time were selected for further tests for suitability as organic fertilizers. Four treatments, i.e., $\mathrm{HCl}(0.25 \mathrm{~N})+\mathrm{KOH}(0.5 \mathrm{~N})$ and $\mathrm{H}_{2} \mathrm{SO}_{4}$ $(0.25 \mathrm{~N})+\mathrm{KOH}(0.5 \mathrm{~N})$ at two temperatures (100 and $150{ }^{\circ} \mathrm{C}$ ), were selected (Table 2). The $\mathrm{pH}$ of an organic fertilizer is crucial, because it alters the $\mathrm{pH}$ of the soil to which it is applied (Yao et al. 2007; Santillan et al. 2014). The soil root zone, especially the rhizosphere, is the active zone of microbial and root activity (Lagos et al. 2015). The $\mathrm{pH}$ of the rhizosphere zone is, therefore, critical in deciding microbial activity (Wang et al. 2016), which in turn regulates the innumerable chemical reactions involved in nutrient transformations and uptake by plant roots. The ideal $\mathrm{pH}$ range for active growth and development of plants and microbes is 6.5-7.5. The EC in these treatments was also safe for use as organic fertilizers. Values $<3.5 \mathrm{dS} \mathrm{m}^{-1}$ are considered safe for soil application (Chen Yiqun et al. 2014). EC is a measure of soluble salts. A high salt content is not desirable, because very high concentrations of soluble salts damage plants through specific ion effects and plasmolysis (Turan et al. 2010; Chauhan et al. 2016). TOC is an important parameter with respect to the maturity of the compost/manure, because a decrease in TOC is desired to attain the optimum $\mathrm{C}: \mathrm{N}$ ratio for soil application. The main aim of composting is to reduce the organic carbon content to achieve a $\mathrm{C}: \mathrm{N}$ ratio of $10: 1-25: 1$, which is ideal for beneficial microorganisms. Approximately 36-56\% of the initial TOC is lost at the end of conventional composting (Nada 2015). Although these desired parameters were achieved by digestion at both temperatures, treatments at the lower temperature of $100{ }^{\circ} \mathrm{C}$ were selected due to the energy savings. Hence, the digest from two treatments, i.e., $\mathrm{HCl}(0.25 \mathrm{~N})+\mathrm{KOH}(0.5 \mathrm{~N})$ and $\mathrm{H}_{2} \mathrm{SO}_{4}$ $(0.25 \mathrm{~N})+\mathrm{KOH}(0.5 \mathrm{~N})$ at $100{ }^{\circ} \mathrm{C}$, were selected for the phytotoxicity tests.

\section{Germination bioassay}

The maturity and safety of conventional composts are generally evaluated by biological methods, such as germination tests (Paradelo et al. 2010) and plant growth analysis or a combination of the two (Kapanen and Itavaara 2001). These tests realistically and efficiently evaluate the compatibility of manure with plants, because they assess the combined effects of several phytotoxic factors present in the manure (Emino and Warman 2004). According to the UK Composting Association, mature compost is one that does not have a negative effect on seed germination or plant growth (Gilbert et al. 2001). Since in the present study, the digest was intended for use in place of compost
Table 2 Selected treatments from laboratory screening experiment

\begin{tabular}{cllll}
\hline Sl. no. & Combination of chemicals & $\mathrm{pH}$ & $\mathrm{EC}\left(\mathrm{dS} \mathrm{m}^{-1}\right)$ & TOC $(\%)$ \\
\hline A & At $100{ }^{\circ} \mathrm{C}, 60 \mathrm{~min}$ & & \\
1. & $\mathrm{HCl}(0.25 \mathrm{~N})+\mathrm{KOH}(0.5 \mathrm{~N})$ & $6.85( \pm 0.35)$ & $1.91( \pm 0.13)$ & $23.93( \pm 0.37)$ \\
2. & $\mathrm{H}_{2} \mathrm{SO}_{4}(0.25 \mathrm{~N})+\mathrm{KOH}(0.5 \mathrm{~N})$ & $7.15( \pm 0.23)$ & $2.10( \pm 0.06)$ & $23.33( \pm 0.47)$ \\
B & $\mathrm{At} 150{ }^{\circ} \mathrm{C}, 60 \mathrm{~min}$ & & \\
3. & $\mathrm{HCl}(0.25 \mathrm{~N})+\mathrm{KOH}(0.5 \mathrm{~N})$ & $6.85( \pm 0.23)$ & $2.01( \pm 0.15)$ & $23.10( \pm 0.05)$ \\
4. & $\mathrm{H}_{2} \mathrm{SO}_{4}(0.25 \mathrm{~N})+\mathrm{KOH}(0.5 \mathrm{~N})$ & $6.9( \pm 0.26)$ & $2.03( \pm 0.04)$ & $21.10( \pm 0.30)$ \\
\hline \multicolumn{4}{l}{ Mean $\pm \mathrm{SD}, n=3)\left(500 \mathrm{~g}\right.$ ground waste, acid $\left(50 \mathrm{ml} \mathrm{kg}^{-1}\right)$, and alkali $\left(100 \mathrm{ml} \mathrm{kg}^{-1}\right)$} &
\end{tabular}


Table 3 Phytotoxicity tests with selected thermochemical treatments

\begin{tabular}{|c|c|c|c|c|c|}
\hline \multicolumn{2}{|c|}{ Sl. no. } & Amaranthus sp. & Vigna unguiculata & Abelmoscus esculentus & Recommended value \\
\hline \multicolumn{6}{|c|}{ Germination index $(\%)$ in Petri dishes ${ }^{a}$} \\
\hline 1. & $\mathrm{HCl}(0.25 \mathrm{~N})+\mathrm{KOH}(0.5 \mathrm{~N})$ & $84.7( \pm 1.8)$ & $89.0( \pm 2.0)$ & $88.5( \pm 1.3)$ & \multirow[t]{2}{*}{ >50 Emino and Warman (2004) } \\
\hline 2. & $\mathrm{H}_{2} \mathrm{SO}_{4}(0.25 \mathrm{~N})+\mathrm{KOH}(0.5 \mathrm{~N})$ & $60.4( \pm 2.5)$ & $56.2( \pm 3.2)$ & $62.6( \pm 1.6)$ & \\
\hline \multicolumn{6}{|c|}{ Germination index $(\%)$ in pro trays ${ }^{\mathrm{a}}$} \\
\hline 1. & $\mathrm{HCl}(0.25 \mathrm{~N})+\mathrm{KOH}(0.5 \mathrm{~N})$ & $82.4( \pm 1.4)$ & $84.2( \pm 3.3)$ & $88.0( \pm 1.0)$ & \multirow[t]{2}{*}{ Asgharipour and Sirousmehr (2012) } \\
\hline 2. & $\mathrm{H}_{2} \mathrm{SO}_{4}(0.25 \mathrm{~N})+\mathrm{KOH}(0.5 \mathrm{~N}$ & $54.5( \pm 0.80)$ & $63.3( \pm 2.7)$ & $64.0( \pm 2.2)$ & \\
\hline
\end{tabular}

${ }^{a}$ Values are mean $\pm \mathrm{SD}$

Table 4 Important properties of composts produced by different methods

\begin{tabular}{llllll}
\hline Compost & $\mathrm{pH}$ & $\mathrm{EC}\left(\mathrm{dS} \mathrm{m}^{-1}\right)$ & $\mathrm{TOC}(\%)$ & $\mathrm{N}(\%)$ & $\mathrm{C}: \mathrm{N}$ \\
\hline MTC & $6.8( \pm 0.35)$ & $1.91( \pm 0.13)$ & $23.93( \pm 0.37)$ & $1.51( \pm 0.03)$ & $15.79( \pm 0.48)$ \\
MMC & $7.1( \pm 0.02)$ & $1.77( \pm 0.09)$ & $18.66( \pm 0.68)$ & $1.36( \pm 0.01)$ & $13.71( \pm 0.61)$ \\
MCC & $7.7( \pm 0.16)$ & $1.95( \pm 0.07)$ & $21.83( \pm 0.25)$ & $1.14( \pm 0.02)$ & $19.16( \pm 0.32)$ \\
VC & $8.4( \pm 0.11)$ & $2.16( \pm 0.10)$ & $16.8( \pm 0.35)$ & $1.59( \pm 0.01)$ & $10.58( \pm 0.15)$ \\
CC & $7.6( \pm 0.32)$ & $1.87( \pm 0.06)$ & $21.16( \pm 0.25)$ & $1.20( \pm 0.01)$ & $17.54( \pm 0.26)$ \\
\hline
\end{tabular}

Values are mean $\pm \mathrm{SD}$

$M T C$ mechanical disintegration followed by thermochemical decomposition, $M M C$ mechanical disintegration followed by microbial composting, $M C C$ mechanical disintegration followed by conventional aerobic composting, $V C$ vermicomposting, $C C$ conventional aerobic composting for crop production, and phytotoxicity tests were essential. The results of the germination tests are presented in Table 3. Composts with a germination index (GI) $\geq 80 \%$ are considered free of phytotoxic compounds (Emino and Warman 2004). A GI $<50 \%$ is considered immature and indicates high phytotoxicity (Zucconi et al. 1985; Emino and Warman 2004). The phytotoxicity of immature composts is attributed to the release of phenolic compounds (Madejon et al. 2001) and volatile organic compounds (Buss and Masek 2014) or the excess accumulation of salts (Salman et al. 2013). In the present experiment, both treatments had GI $>50 \%$, but the treatment of $\mathrm{HCl}$ $(0.25 \mathrm{~N})+\mathrm{KOH}(0.5 \mathrm{~N})$ at $100{ }^{\circ} \mathrm{C}$ and a 60 min reaction time had a GI value $>80 \%$ in petri dishes and pro trays. Therefore, this treatment was selected as the best thermochemical method for processing the waste.

\section{Waste processing efficiency of the selected method compared to existing methods}

In the composting trial, the thermochemical treatment required only $8-14 \mathrm{~h}$ to produce a dried balanced organic fertilizer, including the time taken for sun-drying to attain moisture content suitable for packing. The MMC treatment took 19 days, and $\mathrm{VC}, \mathrm{MCC}$, and $\mathrm{CC}$ took 38, 54, and 90 days, respectively. In $\mathrm{CC}$, the breakdown of complex and simple organic materials is accomplished through the activity of different types of aerobic microbes that become dominant during different stages of composting (Nada 2015); therefore, the method requires more time (Chan et al. 2016). In VC, the process is mediated by earthworms. They are voracious feeders and consume approximately their body weight per day and achieve higher mass reduction than conventional composting (Pattnaik and Reddy 2010). In MCC, the particle size of the waste material is reduced to provide a larger surface area for easy microbe access. Conventional composting can be made more efficient by size reduction (Mishra et al. 2003). In MMC, a consortium of microorganisms is inoculated to accelerate the composting process (Saravanan et al. 2013). Since all these processes are mediated through biological activity, they are slower than the thermochemical process. Chemical analysis of the composts (Table 4) showed that the quality of the organic fertilizer obtained using the new process was comparable to other composts. The $\mathrm{pH}$ of composts from $\mathrm{CC}, \mathrm{VC}$, and $\mathrm{MCC}$ was more alkaline than the thermochemical and microbial composts. In conventional composts and vermicomposts, the degradation process releases salts as a result of the mineralization of organic matter (Pattnaik and Reddy 2010). Compared to conventional composting, vermicomposting is more efficient for the reduction of the bulk dry matter of substrates; therefore, more soluble salts are released into the medium. Moreover, $\mathrm{Ca}$ salts, such as $\mathrm{CaCO}_{3}$, are also synthesized 
and released into the medium by the activity of the calciferous glands in earthworms (Gago-Duport et al. 2008), making vermicomposts more alkaline than conventional composts. The release of exchangeable cations, such as $\mathrm{Ca}$, $\mathrm{Mg}$, and $\mathrm{K}$, in vermicompost increases the $\mathrm{EC}$ of vermicompost (Tognetti et al. 2005). In contrast, in the thermochemical process, the stoichiometry of the acid-alkali reaction was adjusted to obtain a near neutral product that does not pose a threat to soil or plant growth. The TOC content of the thermochemical compost was higher than that of conventional composts. This is expected since in conventional composts, the loss of $\mathrm{C}$ as $\mathrm{CO}_{2}$ occurs through microbial respiration during the degradative phases of composting (Nada 2015). However, this was not reflected in the $\mathrm{C}: \mathrm{N}$ ratio, because the $\mathrm{N}$ content was also higher in this treatment. The longer duration of conventional composting may have resulted in the loss of some of the $\mathrm{N}$ already mineralized by leaching or volatilization (Chan et al. 2016), accounting for the lower values. The only limitation observed for the new method was the absence of microbes due to heating at $100^{\circ} \mathrm{C}$. However, once the manure is applied to soil, it will stimulate microbial activity and improve soil structure, similar to any other organic matter (Zhao et al. 2016). Therefore, this could be treated as an advantage in terms of the absence of pathogenic organisms (FAI 2007).

\section{Performance of vegetables with FOF}

Although the germination tests showed that the FOF posed no threat to the germination of crop seeds, plant growth trials are essential to assess the efficacy and safety on a long-term basis. Germination tests provide an instant picture of phytotoxicity, and plant growth trials assess the prolonged effects of the compost (Zucconi and de Bertoldi 1987). In India, the most commonly used organic manure is FYM (Reddy et al. 2015). Since FOF is intended to be a substitute for FYM, its effect on plant growth is of the utmost importance. When test crops were raised in pots with FOF, the growth and yield attributes showed significant differences between treatments. An increase in yield was observed in the two treatments, where FOF was applied (Table 5). This may be due to the combined effect of the organic and mineral nutrients in FOF as a result of fortification. The mineral portion contributed an initial fast release of nutrients to the plants, followed by a slow release from the organic portion, ensuring nutrient availability for long periods. The beneficial effects of the combined application of organics and inorganics to enhance crop yield and soil health (Jing et al. 2016) have been reported. In the present experiment, the application of FOF at a rate of $5.54 \mathrm{t} \mathrm{ha}^{-1}$ produced the highest fruit yield, which was significantly superior to all other treatments. The yield

Table 5 Effect of FOF on growth and yield of vegetables

\begin{tabular}{|c|c|c|c|c|c|c|}
\hline \multirow[t]{2}{*}{ Treatments } & \multirow[t]{2}{*}{ Height $(\mathrm{cm})$} & \multirow[t]{2}{*}{ No. of branches } & \multirow[t]{2}{*}{ No. of fruits } & \multirow[t]{2}{*}{ Wt of fruit $(\mathrm{g})$} & \multicolumn{2}{|l|}{ Yield } \\
\hline & & & & & g plant $^{-1}$ & $\mathrm{t} \mathrm{ha}^{-1}$ \\
\hline \multicolumn{7}{|l|}{ Chili } \\
\hline $\mathrm{FYM}_{20}+\mathrm{N}_{75} \mathrm{P}_{40} \mathrm{~K}_{25}$ & $40.1^{\mathrm{a}}$ & $18^{\mathrm{a}}$ & $50^{\mathrm{a}}$ & 7.9 & $395^{\mathrm{a}}$ & $10.95^{\mathrm{a}}$ \\
\hline $\mathrm{FOF}_{2.77}$ & $46.6^{b}$ & $25^{\mathrm{b}}$ & $66^{\text {bd }}$ & 8.5 & $561^{\mathrm{b}}$ & $15.50^{\mathrm{b}}$ \\
\hline $\mathrm{FOF}_{5.54}$ & $54.5^{\mathrm{c}}$ & $29^{\mathrm{c}}$ & $74^{\mathrm{c}}$ & 9.0 & $666^{\mathrm{c}}$ & $18.44^{\mathrm{c}}$ \\
\hline $\mathrm{V}_{10}+\mathrm{N}_{75} \mathrm{P}_{40} \mathrm{~K}_{25}$ & $42.2^{\mathrm{d}}$ & $21^{\mathrm{d}}$ & $55^{\mathrm{d}}$ & 7.9 & $435^{\mathrm{d}}$ & $12.01^{\mathrm{a}}$ \\
\hline $\mathrm{CD}(0.05)$ & 1.51 & 0.72 & 0.63 & NS & 16.21 & 1.08 \\
\hline \multicolumn{7}{|l|}{ Tomato } \\
\hline $\mathrm{FYM}_{20}+\mathrm{N}_{75} \mathrm{P}_{40} \mathrm{~K}_{25}$ & $58.2^{\mathrm{a}}$ & $3^{\mathrm{a}}$ & $45.1^{\mathrm{a}}$ & $20.2^{\mathrm{a}}$ & $911.0^{\mathrm{a}}$ & $25.23^{\mathrm{a}}$ \\
\hline $\mathrm{FOF}_{2.77}$ & $68.2^{\mathrm{b}}$ & $8^{\mathrm{b}}$ & $46^{\mathrm{b}}$ & $25.6^{\mathrm{b}}$ & $1177.6^{\mathrm{b}}$ & $32.60^{\mathrm{a}}$ \\
\hline $\mathrm{FOF}_{5.54}$ & $73.5^{\mathrm{c}}$ & $11^{\mathrm{c}}$ & $53^{c}$ & $30.8^{\mathrm{c}}$ & $1632.4^{\mathrm{c}}$ & $45.20^{\mathrm{b}}$ \\
\hline $\mathrm{V}_{10}+\mathrm{N}_{75} \mathrm{P}_{40} \mathrm{~K}_{25}$ & $55.8^{\mathrm{d}}$ & $4^{\mathrm{a}}$ & $45.7^{\mathrm{d}}$ & $21.5^{\mathrm{d}}$ & $982.5^{\mathrm{a}}$ & $27.20^{\mathrm{a}}$ \\
\hline $\mathrm{CD}(0.05)$ & 1.06 & 1.27 & 0.21 & 0.13 & 96.82 & 8.73 \\
\hline \multicolumn{7}{|l|}{ Brinjal } \\
\hline $\mathrm{FYM}_{20}+\mathrm{N}_{75} \mathrm{P}_{40} \mathrm{~K}_{25}$ & $78.3^{\mathrm{a}}$ & $7^{\mathrm{a}}$ & $52^{\mathrm{a}}$ & $28^{\mathrm{a}}$ & $1449^{\mathrm{a}}$ & $40.16^{\mathrm{a}}$ \\
\hline $\mathrm{FOF}_{2.77}$ & $102.2^{\mathrm{b}}$ & $12^{\mathrm{b}}$ & $59^{\mathrm{b}}$ & $38^{\mathrm{b}}$ & $2240^{\mathrm{b}}$ & $62.04^{\mathrm{ab}}$ \\
\hline $\mathrm{FOF}_{5.54}$ & $106.4^{\mathrm{c}}$ & $15^{\mathrm{c}}$ & $67^{\mathrm{c}}$ & $42^{\mathrm{c}}$ & $2814^{\mathrm{c}}$ & $77.83^{\mathrm{b}}$ \\
\hline $\mathrm{V}_{10}+\mathrm{N}_{75} \mathrm{P}_{40} \mathrm{~K}_{25}$ & $85.6^{\mathrm{d}}$ & $9^{\mathrm{a}}$ & $54^{\mathrm{d}}$ & $33^{\mathrm{d}}$ & $1781^{\mathrm{d}}$ & $49.30^{\mathrm{a}}$ \\
\hline $\mathrm{CD}(0.05)$ & 3.21 & 2.13 & 1.42 & 2.36 & 239.14 & 23.63 \\
\hline
\end{tabular}

FYM farm yard manure, FOF fortified organic fertilizer, $V$ vermicompost in $\mathrm{t} \mathrm{ha}^{-1}, N, P$ and $K$ in $\mathrm{kg} \mathrm{ha}^{-1}, C D$ critical difference, $N S$ not significant

a,b,c,d Significant difference between data 
increased by $68.6 \%$ compared to FYM and $58.5 \%$ compared to vermicompost. Tomato and brinjal also showed the same trend, with much greater yield increases (tomato: 79 and $71.3 \%$; brinjal: 94.2 and $71.2 \%$ ). The effects of FOF for increasing crop yield and improving the soil properties have been reported (Jayakrishna and Thampatti 2016; Leno et al. 2016). The yields of the vermicompost treatments, although lower than that of FOF, were higher than FYM. Vermicompost contains higher levels of nutrients than FYM (Venkatesha et al. 2015), in addition to secondary and micronutrients and growth stimulating hormones (Kundu et al. 2015), which contributed to enhanced growth and yield of plants. Thus, the results revealed that the FOF could act as a substitute for the combined use of organic manure and chemical fertilizer for crop production.

\section{Details of the new process and characteristics of the product}

In the new process, degradable waste segregated at the source was subjected to size reduction by wet grinding (Sun and Cheng 2002) to reduce the particle size to increase the specific surface area (Zhang et al. 2014). The waste was then allowed to react with $\mathrm{HCl}(0.25 \mathrm{~N} \mathrm{HCl}$, $50 \mathrm{ml} \mathrm{kg} \mathrm{kg}^{-1}$ waste) followed by $\mathrm{KOH}\left(0.5 \mathrm{~N}, 100 \mathrm{ml} \mathrm{kg}^{-1}\right)$ for $30 \mathrm{~min}$ at $100{ }^{\circ} \mathrm{C}$ and ambient pressure. Thermal treatment helped the disintegration of the cell wall and membrane to solubilize the organic matter (Audrey et al. 2011). An initial drying step was performed by the addition of sterilized coir pith, wood charcoal or saw dust at the rate of $40 \mathrm{~g} \mathrm{~kg}^{-1}$ waste before completely drying the waste in the sun or in an electric drier. Since soils in general are depleted of minerals, fortification with calculated doses of essential plant nutrients was performed to create a balanced organic fertilizer. The sources of nutrients used for the fortification and their average nutrient contents are given in
Table 6. A $1 \mathrm{~kg}$ sample of fresh waste would yield $\sim 200-225 \mathrm{~g}$ of FOF. The product characteristics before and after fortification are presented in Table 7 . The texture of the dried digest was lumpy, but the addition of coir pith made it free flowing. The reaction was neutral, EC within safe limit, and the $\mathrm{C}: \mathrm{N}$ ratio was $<20$. A slight increase in TOC was observed after fortification, which might be due to the added coir pith. When applied to soil for crop production, organic fertilizers should improve the health of the soil and crop (Zhang et al. 2016). Hence, the manurial value of the added product is important. The nutrient content of the digest was comparable to those of ordinary composts in terms of primary major nutrients. The low contents of secondary and micronutrients were addressed by fortification with organic and inorganic sources (Table 6). The increase in the concentrations of $\mathrm{S}, \mathrm{Fe}, \mathrm{Mn}$, and $\mathrm{Cu}$ in the FOF, although they were not added, may have come from the sources of the other nutrients. The contents of the heavy metals $\mathrm{Pb}, \mathrm{Cd}, \mathrm{Ni}, \mathrm{Cr}$, and As were far below the permissible limits (FAI 2007), indicating that the organic fertilizer was safe for use. Thus, the organic fertilizer produced by the new process (Fig. 1) can be widely used in agriculture to supply sufficient organic matter for the carbon-craving soil and balanced quantities of essential nutrients for plants. The fertilizer could also be used as a potting medium for container cultivation and as a growth medium for germinating seeds in pro trays (Jayakrishna and Thampatti 2016). There was no foul smell produced by the FOF, even when the raw waste was rotten and had a bad odor.

The process does not produce any type of effluent or pollutant, since the digest is utilized for the production of FOF. Therefore, the process does not require pollution control efforts. The new process provides a quick and sustainable solution for waste disposal and recycling of organic residue. These small-scale processing units prevent
Table 6 Sources used for fortification with their average nutrient contents

\begin{tabular}{llllll}
\hline Properties & Groundnut cake & Rock phosphate & Wood ash & Zinc sulfate & Borax \\
\hline $\mathrm{N}(\%)$ & 6.80 & - & 0.06 & 0.0005 & - \\
$\mathrm{P}(\%)$ & 1.41 & 8.92 & 0.94 & - & - \\
$\mathrm{K}(\%)$ & 1.14 & - & 12.2 & - & - \\
$\mathrm{Ca}(\%)$ & 0.08 & 15.33 & 9.18 & - & 0.002 \\
$\mathrm{Mg}(\%)$ & 0.34 & 0.21 & 1.42 & 0.11 & - \\
$\mathrm{S}(\%)$ & 0.09 & - & 0.01 & - & 0.001 \\
$\mathrm{Fe}\left(\mathrm{mg} \mathrm{kg}^{-1}\right)$ & 215.70 & - & 1.94 & 0.50 & 0.38 \\
$\mathrm{Mn}\left(\mathrm{mg} \mathrm{kg}^{-1}\right)$ & 52.17 & - & 0.66 & - & - \\
$\mathrm{Cu}\left(\mathrm{mg} \mathrm{kg}^{-1}\right)$ & 15.85 & - & 0.01 & - & 0.50 \\
$\mathrm{Zn}$ & $68.54 \mathrm{mg} \mathrm{kg}^{-1}$ & - & $0.07 \mathrm{mg} \mathrm{kg}^{-1}$ & $20.86 \%$ & - \\
$\mathrm{B}$ & $17.50 \mathrm{mg} \mathrm{kg}$ & -1 & - & - & $10.5 \%$ \\
$\mathrm{Mo}\left(\mathrm{mg} \mathrm{kg}^{-1}\right)$ & 1.01 & - & 0.01 & - & - \\
\hline
\end{tabular}


Table 7 Physical and chemical properties of thermochemical digest with and without fortification (mean \pm SD)

\begin{tabular}{|c|c|c|c|}
\hline Physical and chemical properties & Without fortification & With fortification & Recommended value (FAI 2007) \\
\hline Color & Brownish black & Brownish black & Dark brown to black \\
\hline Odor & Odorless & Odorless & Absence of foul odor \\
\hline $\mathrm{pH}$ & Neutral & Neutral & $6.5-7.5$ \\
\hline $\mathrm{EC}\left(\mathrm{dS} \mathrm{m} \mathrm{m}^{-1}\right)$ & $1.91( \pm 0.13)$ & $2.13( \pm 0.09)$ & $<4$ \\
\hline Texture & Lumpy & Free flowing & \\
\hline Moisture (\%) & $18.5 \pm 1.6$ & $16 \pm 1.1$ & $15-25$ \\
\hline TOC (\%) & $23.93 \pm 0.37$ & $24.42 \pm 0.12$ & $>16$ \\
\hline $\mathrm{C}: \mathrm{N}$ ratio & $15.79 \pm 0.48$ & $12.16 \pm 0.60$ & $<20: 1$ \\
\hline Pathogens & Nil & Nil & Nil \\
\hline $\mathrm{Pb}\left(\mathrm{mg} \mathrm{kg}^{-1}\right)$ & $1.38 \pm 2.18$ & $1.08 \pm 0.76$ & $<100$ \\
\hline $\mathrm{Cd}\left(\mathrm{mg} \mathrm{kg}^{-1}\right)$ & BDL & BDL & $<5$ \\
\hline $\mathrm{Ni}\left(\mathrm{mg} \mathrm{kg}^{-1}\right)$ & $3.6 \pm 1.85$ & $5.65 \pm 2.59$ & $<50$ \\
\hline $\mathrm{Cr}\left(\mathrm{mg} \mathrm{kg}^{-1}\right)$ & $8.58 \pm 2.80$ & $11.68 \pm 5.59$ & $<50$ \\
\hline As $\left(\mathrm{mg} \mathrm{kg}^{-1}\right)$ & $\mathrm{BDL}$ & $\mathrm{BDL}$ & $<10$ \\
\hline Manurial value & & & Rate and source of fortification \\
\hline $\mathrm{N}(\%)$ & $1.51 \pm 0.03$ & $2.01 \pm 0.11$ & 0.5 (Ground nut cake) \\
\hline $\mathrm{P}(\%)$ & $0.42 \pm 0.22$ & $0.95 \pm 0.15$ & 0.5 (Rock phosphate) \\
\hline $\mathrm{K}(\%)$ & $0.66 \pm 0.31$ & $1.1 \pm 0.20$ & 0.5 (Wood ash) \\
\hline $\mathrm{Ca}\left(\mathrm{mg} \mathrm{kg}^{-1}\right)$ & $255 \pm 15$ & $2700 \pm 120$ & \\
\hline $\mathrm{Mg}\left(\mathrm{mg} \mathrm{kg}^{-1}\right)$ & $300 \pm 30$ & $1200 \pm 150$ & \\
\hline $\mathrm{S}\left(\mathrm{mg} \mathrm{kg}^{-1}\right)$ & $299 \pm 42$ & $650 \pm 122$ & - \\
\hline $\operatorname{Mn}\left(\mathrm{mg} \mathrm{kg}^{-1}\right)$ & $10.6 \pm 3.04$ & $25.1 \pm 3.2$ & - \\
\hline $\mathrm{Zn}\left(\mathrm{mg} \mathrm{kg}^{-1}\right)$ & $8.25 \pm 0.27$ & $66.6 \pm 4.5$ & 50 (Zinc sulfate) \\
\hline $\mathrm{Cu}\left(\mathrm{mg} \mathrm{kg}^{-1}\right)$ & $2.3 \pm 0.20$ & $14.5 \pm 2.5$ & - \\
\hline $\mathrm{B}\left(\mathrm{mg} \mathrm{kg}^{-1}\right)$ & $0.27 \pm 0.08$ & $0.55 \pm 0.05$ & 0.5 (Borax) \\
\hline
\end{tabular}

$B D L$ below detectable level

the need for the collection and transportation of waste to centralized processing plants, resulting in huge transportation cost savings. The process could be scaled up and operated in factory mode in the case of huge demand.

\section{The prototype machine}

The prototype machine of $1.5 \mathrm{~m}^{3}$ and a capacity of $20 \mathrm{~kg}$ (Fig. 2) occupy a floor space of only $2.5 \mathrm{~m}^{2}$. It was specifically designed to meet the requirements of residential colonies/apartments in densely populated cities. The machine has two main parts: a grinding unit with a $2 \mathrm{HP}$ motor and a reactor unit with temperature control and constant stirring facility. Segregated waste is dumped into the grinding unit. Uniformly homogenized mass is automatically transferred to the reactor unit and allowed to react with the chemicals at the specified temperature and time. The processed organic fertilizer can be collected by opening the valve in the reactor. The water requirement for the process is very low (only for grinding and cleaning), and the electricity consumption for the operation of the machine is only $3 \mathrm{~kW} \mathrm{~h}$.

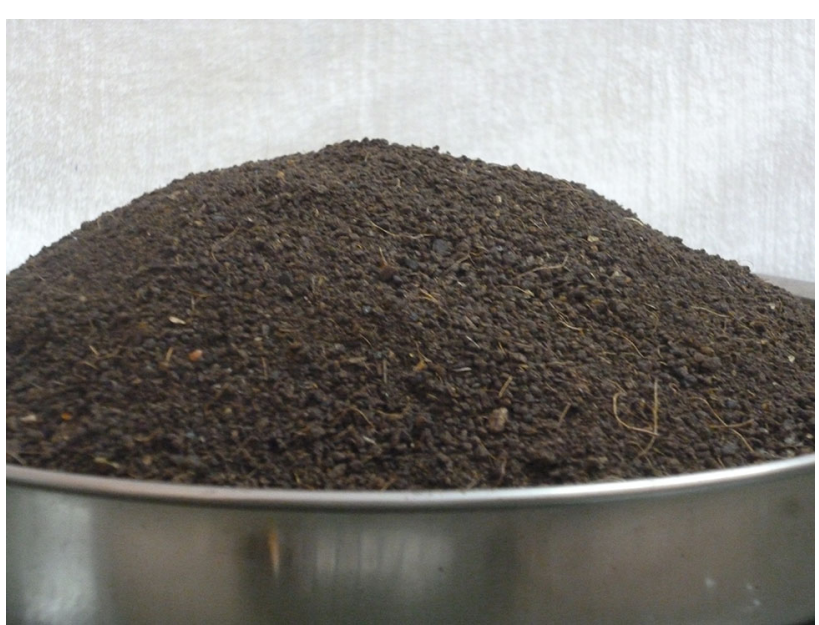

Fig 1 Organic fertilizer produced by the new process

\section{Public evaluation of the new process}

The unit is installed in a residential colony for public evaluation and is processing $\sim 75-110 \mathrm{~kg}$ of waste daily, collected from 75 houses. Two women workers run the 


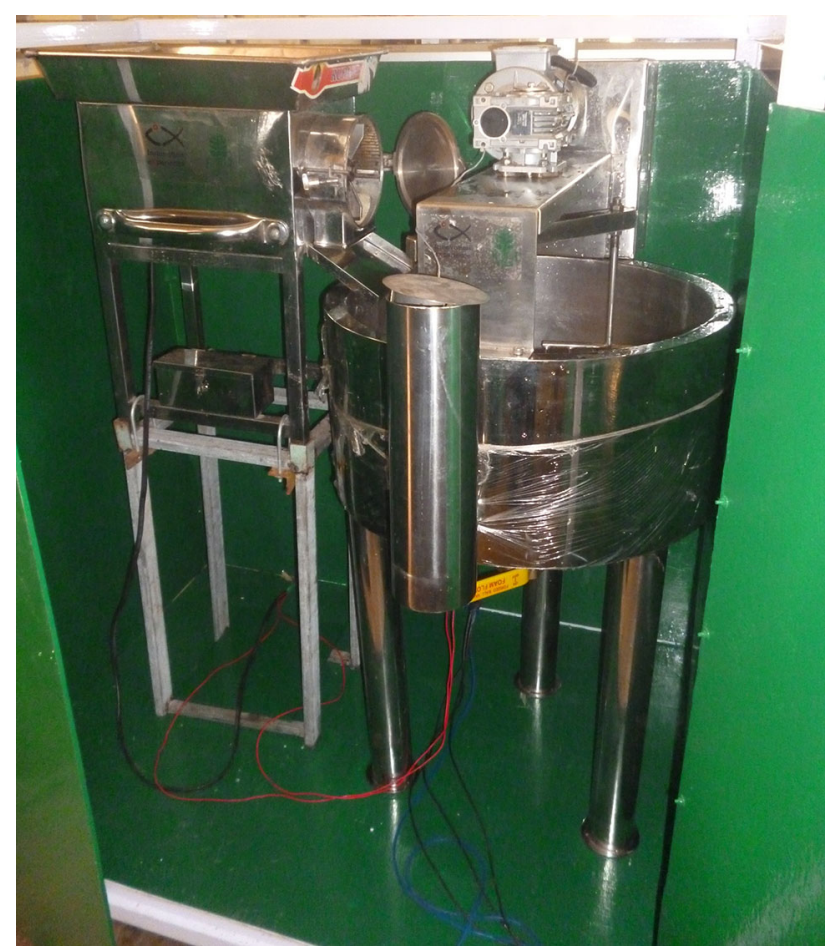

Fig 2 Prototype waste processing machine (inside view)

unit. Degradable waste from each house is segregated and kept in separate buckets supplied to the residents for the purpose. Depending on the quantity of waste to be processed, one or two batches are operated per day. The unit works on all days except Sundays. The quantity of waste processed varies from 2000 to $2600 \mathrm{~kg}$ per month. The fortified manure produced by the unit is either sold as a value added, balanced organic fertilizer or as a potting medium for container cultivation at four times the price of ordinary organic manure.

\section{Cost analysis}

Since the method is new and remains to be popularized, it is essential to determine the economic feasibility for largescale adoption. Hence, the cost analysis was performed on the basis of the actual operating costs and income generated during June 2015 to December 2015 by the waste processing unit installed in the residential colony in Trivandrum. The items of expenditure included collection charges, labor charges, and cost of materials needed for processing, including chemicals and other miscellaneous expenditures. The average total cost per month was US $\$ 294$ (US \$0.128 per kg fresh waste). The dried FOF was sold at a rate of US $\$ 0.91$ per $\mathrm{kg}$. The average production per month was $575 \mathrm{~kg}$ FOF. Thus, the average total income generated per month was US \$523 (0.229 US \$ per kg fresh waste). Hence, a net profit of US \$229 per month (US $\$ 0.101$ per $\mathrm{kg}$ waste) is generated. This makes the new process even more attractive. Waste processing using this method is a solution for the safe disposal of waste and also for income generation for the unemployed.

\section{Conclusions}

Thermochemical processing of degradable waste with $\mathrm{HCl}$ $\left(0.25 \mathrm{~N}, 50 \mathrm{ml} \mathrm{kg}{ }^{-1}\right)$ for 30 min followed by $\mathrm{KOH}(0.5 \mathrm{~N}$, $100 \mathrm{ml} \mathrm{kg}^{-1}$ ) for $30 \mathrm{~min}$ at $100{ }^{\circ} \mathrm{C}$ and ambient pressure provides a quick and sustainable solution for hygienic waste disposal and the production of organic fertilizer. The method has the merits of processing waste on the day of generation at the source without the formation of byproducts, thus avoiding environmental problems connected with open dumping and transportation to centralized processing plants. Large areas being used as landfill sites could be used for productive purposes. The process will lead to the large-scale generation of balanced organic fertilizer for soil application, which will enhance crop yields and improve soil health and environmental quality. This could be a replicable model of waste processing, especially for developing countries.

Acknowledgements The authors gratefully acknowledge the financial support provided for 2 years by the Department of Agricultural Research and Education, Indian Council of Agricultural Research, Ministry of Agriculture, Government of India for undertaking this project. Authors are thankful to Dr. Samuel Mathew, Professor and Head, Aromatic and Medicinal Plants Research Institute, Odakkali, Kerala and Dr. P. Sureshkumar, Professor and Head, Radiotracer Laboratory, College of Horticulture, Thrissur for their valuable suggestions in drafting the manuscript.

\section{Compliance with ethical standards}

Conflict of interest The authors declare that they have no conflict of interest.

Open Access This article is distributed under the terms of the Creative Commons Attribution 4.0 International License (http://crea tivecommons.org/licenses/by/4.0/), which permits unrestricted use, distribution, and reproduction in any medium, provided you give appropriate credit to the original author(s) and the source, provide a link to the Creative Commons license, and indicate if changes were made.

\section{References}

Abbruzzini TF, Silva CA, Andrade DA, Carneiro WJO (2014) Influence of digestion methods on the recovery of iron, zinc, nickel, chromium, cadmium and lead contents in 11 organic residues. Rev Bras Cienc Solo 38:166-176

Abu Qdais H, Al-Widyan M (2016) Evaluating composting and cocomposting kinetics of various agro-industrial wastes. Int $\mathrm{J}$ Recycl Org Waste Agricult 5:273-280

Adela NB, Nasrin AB, Loh SK, Choo YM (2014) Bioethanol production by fermentation of oil palm empty fruit bunches 
pretreated with combined chemicals. J Appl Environ Biol Sci 4:234-242

Ahmad R, Khalid A, Arshad M, Zahir ZA, Naveed M (2006) Effect of raw (un-composted) and composted organic waste material on growth and yield of maize (Zea mays L.). Soil Environ 25(2):135-142

Annepu RK (2012) Sustainable solid waste management in India. M.S. Thesis, Columbia University

Asgharipour MR, Sirousmehr AR (2012) Comparison of three techniques for estimating phytotoxicity in municipal solid waste compost. Ann Biol Res 3(2):1094-1101

Audrey P, Julien L, Christophe D, Patrick L (2011) Sludge disintegration during heat treatment at low temperature: a better understanding of involved mechanisms with a multiparametric approach. Biochem Eng J 54(3):178-184

Baishya P, Mahanta DK, Singh SB (2016) Waste composting a sustainable practice. Int J Innov Res Sci Technol 2:537-543

Bensah EC, Mensah M (2013) Chemical pretreatment methods for the production of cellulosic ethanol: technologies and innovations. Int J Chem Eng 2013:21. doi:10.1155/2013/719607

Bernal MP, Alburquerque JA, Moral R (2009) Composting of animal manures and chemical criteria for compost maturity assessment. A review. Bioresour Technol 100(22):5444-5453

Buss W, Masek O (2014) Mobile organic compounds in biochar-a potential source of contamination-phytotoxic effects on cress seed (Lepidium sativum) germination. $\mathrm{J}$ Environ Manage 137:111-119

Chan MT, Selvam A, Wong JWC (2016) Reducing nitrogen loss and salinity during 'struvite' food waste composting by zeolite amendment. Bioresour Technol 200:838-844

Chauhan A, Rajput N, Kumar D, Kumar A, Chaudhry AK (2016) Effect of different salt concentration on seed germination and seedling growth of different varieties of oat (Avena sativa L.). Int J Inf Res Rev 3(7):2627-2632

Chen Yiqun Yu, Fang Liang Shengwen, Zongping Wang, Zizheng Liu, Ya Xiong (2014) Utilization of solar energy in sewage sludge composting: fertilizer effect and application. Waste Manage 34(11):2014-2021

Du Y, Feng H, Zhang K, Hu LF, Fang CR, Shen DS, Long YY (2014) Role of iron in $\mathrm{H}_{2} \mathrm{~S}$ emission behavior during the decomposition of biodegradable substrates in landfill. J Hazard Mater 272:36-41

Dube R, Nandan V, Dua S (2014) Waste incineration for urban India: valuable contribution to sustainable MSWM or inappropriate high-tech solution affecting livelihoods and public health? Int $\mathrm{J}$ Environ Technol Manag 17(2/3/4):199-214

Elemike EE, Oseghale OC, Okoye AC (2015) Utilization of cellulosic cassava waste for bio-ethanol production. J Environ Chem Eng 3:2797-2800

Emino ER, Warman PR (2004) Biological assay for compost quality. Compost Sci Util 12(4):342-348

FAI (2007) The Fertiliser (Control) Order 1985. The Fertiliser Association of India, New Delhi

Gago-Duport L, Briones MJI, Rodríguez JB, Covelo B (2008) Amorphous calcium carbonate biomineralization in the earthworm's calciferous gland: pathways to the formation of crystalline phases. J Struct Biol 162:422-435

Gariglio NF, Buyatti MA, Pilatti RA, Gonzalez Rossia DE, Acosta MR (2002) Use of a germination bioassay to test compost maturity of willow (Salix sp.) sawdust. NZ J Crop Hortic Sci 30:135-139

Gilbert EJ, Riggle DS, Holland FD (2001) Large scale composting: a practical manual for the UK. The Composting Association, Northamptonshire

Greenberg AE, Clesceri LS, Eaton AD (1992) Standard methods for the examination of water and wastewater, 18th edn. American Public Health Association, Washington
Jayakrishna, Thampatti KCM (2016) Standardisation of growth medium based on thermo chemical digest produced from degradable solid waste by rapid conversion technology. Int $\mathrm{J}$ Appl Pure Sci Agric 2(10):76-80

Jing D, Wang M, Zhang H, Li S (2016) Effects of chicken manure coapplied with nitrogen fertilizer on soil organic carbon oxidation stability and carbon pool management index in kidney bean/maize rotation soil. Trans Chin Soc Agric Mach 47(8):192-200

Junoh H, Palanisamy K, Yip CH, Pua FL (2015) Optimization of $\mathrm{NaOH}$ thermo-chemical pretreatment to enhance solubilisation of organicfood waste by response surface methodology. Intl J Chem Mol Nucl Mater Metall Eng 9(12):1282-1288

Kapanen A, Itavaara M (2001) Ecotoxicity tests for compost applications. Ecotoxicol Environ Saf 49:1-16

Kim MH, Kim JW (2010) Comparison through a LCA evaluation analysis of food waste disposal options from the perspective of global warming and resource recovery. Sci Total Environ 408(19):3998-4006

Kundu S, Chakraborty S, Roy D, Ghosh B, Dutta P (2015) Studies on organic nutrition in improving yield and quality of ber cv. BAU Kul-1. J Crop Weed 11(2):14-18

Lagos L, Maruyama F, Nannipieri P, Mora ML, Ogram A, Jorquera MA (2015) Current overview on the study of bacteria in the rhizosphere by modern molecular techniques: a mini-review. J Soil Sci Plant Nutr 15:504-523

Lal R (2015) Soil carbon sequestration in agro ecosystems of India. J Indian Soc Soil Sci 63(2):125-143

Leno N, Sudharmaidevi CR, Meera AV (2016) Fertility evaluation and manurial effect of organic manure produced from degradable solid waste by rapid conversion technology. Adv Life Sci 5(11):4433-4436

Lim SL, Wu TY, Lim PN, Shak KPY (2015) The use of vermicompost in organic farming: overview, effects on soil and economics. J Sci Food Agric 95(6):1143-1156

Lim SL, Lee LH, Wu TY (2016) Sustainability of using composting and vermicomposting technologies for organic solid waste biotransformation: recent overview, greenhouse gases emissions and economic analysis. J Clean Prod 111:262-278

Madejon E, Burgos P, Murillo JM, Cabrera F (2001) Phytotoxicity of organic amendments on activities of select soil enzymes. Commun Soil Sci Plant Anal 32:2227-2239

Maeda RN, Barcelos CA, Anna LMS, Pereira N Jr (2013) Cellulase production by Penicillium funiculosum and its application in the hydrolysis of sugarcane bagasse for second generation ethanol production by fed batch operation. J Biotechnol 163:38-44

Mishra RV, Roy RN, Hiraoka H (2003) On-farm composting methods. Food and Agricultural Organisation of the United Nation, Rome

Nada WM (2015) Stability and maturity of maize stalks compost as affected by aeration rate, $\mathrm{C} / \mathrm{N}$ ratio and moisture content. J Soil Sci Plant Nutr 15(3):751-764

OECD-OCDE (Organization for Economic Co operation and Development (2006) OECD guidelines for the testing of chemicals test no. 208: terrestrial plant test: seedling emergence and seedling growth test. OECD Publishing, Paris

Paradelo R, Villada A, Gonzalez D, Barral MT (2010) Evaluation of the toxicity of heavy metals and organic compounds in compost by means of two germination-elongation tests. Fresenius Environ Bull 19:956-962

Pattnaik S, Reddy MV (2010) Nutrient status of vermicompost of urban green waste processed by three earthworm speciesEisenia fetida, Eudrilus eugeniae, and Perionyx excavates. Appl Environ Soil Sci 2010:13. doi:10.1155/2010/967526 
Qadir M, Oster JD, Schubert S, Noble AD, Sahrawat KL (2007) Phytoremediation of sodic and saline-sodic soils. Adv Agron 96:197-247

Reddy KS, Mohanty M, Rao DLN, Singh M, Rao AS, Pandey M, Blamey FPC, Dalal RC, Dixit SK, Menzies NW (2015) Nutrient mass balances and leaching losses from a farmyard manure pit in Madhya Pradesh. J Indian Soc Soil Sci 63(1):64-68

Roignavarro AF, Lopez FJ, Hernandez F (1996) Application of the azomethine- $\mathrm{H}$ method to the determination of boron in workplace atmospheres from ceramic factories. Fres $\mathbf{J}$ Anal Chem 356:103-106

Salman G, Hameed A, Alatar A, Hegazy A, Khan MA (2013) Seed germination ecology of Cyperus arenarius - a sand binder from Karachi coast. Pak J Bot 45(2):493-496

Santillan MY, Moreno FP, Garcia FP, Sandooval AAO (2014) Effect of the application of manure of cattle on the properties chemistry of soil in Tizayuca, Hidalgo. M Int J Appl Sci Tech 4(3):67-72

Saravanan P, Kumar SS, Ajithan C (2013) Eco-friendly practice of utilization of food wastes. Int J Pharm Sci Innov 2013:14-17

Sasaki N, Suehara KI, Kohda J, Nakano Y, Yano T (2003) Effects of $\mathrm{CN}$ ratio and $\mathrm{pH}$ of raw materials on oil degradation efficiency in a compost fermentation process. J Biosci Bioeng 96:47-52

Sharma R, Palled V, Sharma-Shivappa RR (2013) Potential of potassium hydroxide pretreatment of switchgrass for fermentable sugar production. Osborne J Appl Biochem Biotechnol 169(3):761-772

Suarez DL, Wood JD, Lesch SM (2006) Effect of SAR on water infiltration under a sequential rain-irrigation management system. Agr Water Manage 86(1-2):150-164

Sun Y, Cheng J (2002) Hydrolysis of lignocellulosic materials for ethanol production: a review. Bioresour Technol 83(1):1-11

Sundberg C, Yu D, Franke-Whittle I, Kauppi S, Smars S, Insam H, Romantschuk M, Jonsson H (2013) Effects of pH and microbial composition on odour in food waste composting. Waste Manag 33(1):204-211

Thys RCS, Aires AG (2013) The effect of acid hydrolysis on the technological functional properties of pinhão (Araucaria brasiliensis) starch. Ciênc Tecnol Aliment Campinas 33:89-94

Tognetti C, Laos F, Mazzarino MJ, Hernandez MT (2005) Composting vs. vermicomposting: a comparison of end product quality. Compost Sci Util 13(1):6-13

Turan MA, Elkarim AHA, Taban A, Taban S (2010) Effect of salt stress on growth and ion distribution and accumulation in shoot and root of maize plant. Afr J Agric Res 5(7):584-588
Venkatesha MM, Krishnamurthy N, Tuppad GB, Venkatesh KT (2015) Yield, economics and nutrient uptake of aerobic rice cultivars as influenced by INM practices. Res Environ Life Sci $8(1): 113-118$

Wang J, Xue C, Song Y, Wang L, Huang Q, Shen Q (2016) Wheat and rice growth stages and fertilization regimes alter soil bacterial community structure, but not diversity. Front Microbiol $7: 1207$

Wu TY, Lim SL, Lim PN, Shak KPY (2014) Biotransformation of biodegradable solid wastes into organic fertilizers using composting or/and vermicomposting. Chem Eng Trans 39:1579-1584

Rana R, Ganguly R, Gupta AK (2013) An assessment of solid waste management system in Chandigarh city, India. Electron $\mathbf{J}$ Geotech Eng 20(Bundle 6):1547-1572

Yao LX, Li GL, Tu SH, Gavin S, He ZH (2007) Salinity of animal manure and potential risk of secondary soil salinization through successive manure application. Sci Total Environ 383:106-114

Zhang C, Su H, Baeyens J, Tan T (2014) Reviewing the anaerobic digestion of food waste for biogas production. Renew Sust Energ Rev 38(1215):383-392

Zhang P, Chen X, Wei T, Yang Z, JiaZ Yang B, Han Q, Ren X (2016) Effects of straw incorporation on the soil nutrient contents, enzyme activities, and crop yield in a semiarid region of China. Soil Tillage Res 160:65-72

Zhao B, Zhang J, Yu Y, Karlen DL, Hao X (2016) Crop residue management and fertilization effects on soil organic matter and associated biological properties. Environ Sci Pollut Res 23(17):17581-17591

Zhu S, Huang W, Huang W, Wang K, Chen Q, Wu Y (2015) Pretreatment of rice straw for ethanol production by a two-step process using dilute sulfuric acid and sulfomethylation reagent. Appl Energy 154:190-196

Zucconi F, de Bertoldi M (1987) Compost specifications for the production and characterization of compost from municipal solid waste. In: de Bertoldi M, Ferranti MP, L'Hermite P, Zucconi F (eds) Compost: production, quality and use. Elsevier, New York, pp 30-50

Zucconi F, Monaco A, Forte M (1985) Phytotoxins during the stabilization of organic matter. In: Gasser JKR (ed) Composting of agricultural and other wastes. Elsevier, New York, pp 73-86 